\title{
Genetic variation of Prochilodus lineatus (Valenciennes, 1836) from Paraná, Baía, Miranda, and Corumbá rivers, Brazil
}

\author{
E. Revaldaves ${ }^{1}$, E. Renesto ${ }^{2}$ and J.R. Gold ${ }^{3}$ \\ ${ }^{1}$ Programa de Pós-Graduação e Ecologia de Ambientes Aquáticos Continentais, \\ Núcleo de Pesquisas em Limnologia, Ictiologia e Aquicultura, \\ Universidade Estadual de Maringá, Maringá, PR, Brasil \\ ${ }^{2}$ Departamento de Biotecnologia, Genética e Biologia Celular, \\ Núcleo de Pesquisas em Limnologia, Ictiologia e Aquicultura, \\ Universidade Estadual de Maringá, Maringá, PR, Brasil \\ ${ }^{3}$ Department of Biology, University of New Mexico, Albuquerque, NM, USA \\ Corresponding author: E. Revaldaves \\ E-mail: erevaldaves@hotmail.com
}

Genet. Mol. Res. 15 (4): gmr.15048829

Received May 23, 2016

Accepted July 5, 2016

Published October 5, 2016

DOI http://dx.doi.org/10.4238/gmr.15048829

Copyright (C) 2016 The Authors. This is an open-access article distributed under the terms of the Creative Commons Attribution ShareAlike (CC BY-SA) 4.0 License.

ABSTRACT. The curimbatá (Prochilodus lineatus) is one of the
migratory species in the Paraná River Basin impacted by the construction
of dams. Mitochondrial DNA sequences and random amplified
polymorphic DNA (RAPD) fragments were used to investigate genetic
variability and geographic structure of five populations of curimbatá
from the Paraná River Basin. A total of 1815 bp from seven polymerase
chain reaction-amplified fragments representing five protein-coding
mitochondrial genes were sequenced from 12 individuals. Estimates of
nucleotide sequence divergence ranged from 0.00 to $0.95 \%$. A total of
86 RAPD markers from 58 individuals were detected. Results from the

Genetics and Molecular Research 15 (4): gmr.15048829 
Fisher exact test indicated that $P$. lineatus is not genetically subdivided, although significant differences in the frequencies of a few RAPD fragments were observed. This study provides useful information for stocking and management programs for resource planning of $P$. lineatus.

Key words: Curimbatá; RAPD; Mitochondrial DNA; Dams; Single stock

\section{INTRODUCTION}

Development of a country requires increased energy and food supply. For this reason, reservoirs have been built in almost all hydrographic basins of Brazil. Despite their economic benefits, reservoirs affect the hydrologic regime of rivers and, consequently, the sustainability of living resources (Agostinho et al., 2008; Agostinho et al., 2009). The Paraná River is the second longest river in South America $(4695 \mathrm{~km})$ and has been intensively dammed. The first large reservoir in the upper Paraná River was the Paranaíba hydropower reservoir; the reservoir was closed in 1901. However, since then, more than 145 large dams have been constructed; $70 \%$ of which are used for hydroelectricity (Agostinho et al., 2007). Most large tributaries of the Paraná River, including the Paranaíba, Grande, Tietê, and Paranapanema rivers, and even the main channel of the Paraná River, have been transformed into a cascade of reservoirs. The Paraguay River, the major affluent of Paraná River, has not been dammed for hydroelectric power generation. The discharge control promoted by these dams has altered the seasonal cycles of floods and, consequently, the habitat quality and dynamics of the biota (Agostinho et al., 2008).

Dams are formidable barriers to the dispersal of migratory species and may have disrupted the historical population structure of many aquatic species in the Paraná River. The curimbatá (Prochilodus lineatus) is one of the impacted migratory species in the Paraná River Basin, because it requires distinct floodplain habitats to complete its life cycle (Gomes and Agostinho, 1997). At the same time, the curimbata is of considerable economic importance in the upper Paraná and Paraguay River Basins (Resende et al., 1996; Rossi et al., 2007), and there are data that indicate significant decreases in curimbatá in the Paraná River Basin (Agostinho et al., 1999; Gubiani et al., 2007). To offset perceived declines, hatchery-raised curimbatá fry were stocked into various reservoirs in the Paraná River Basin between 1979 and 1995 (Companhia Energética de São Paulo, 1996). Stocking was carried out with clear political objectives and pseudo-conservationist, institutional marketing (Agostinho et al., 2005). The stocking program was executed without knowledge of the genetic structure of the curimbatá within the Paraná River Basin and without consideration of future genetic monitoring and evaluation (Agostinho et al., 2009). There are no data confirming the success of this stocking program.

Informed and effective management should include strategies to minimize potential negative genetic interactions between cultured and wild fish (Ferguson, 1994) and there should be knowledge of the population structure of species important to the fishery industry (Allendorf et al., 1987). A diverse array of molecular-genetic tools has become available for high-resolution genetic studies of population-level processes. These include restriction endonuclease analysis and direct sequencing of mitochondrial $(\mathrm{mt})$ DNA, use of polymerase chain reaction (PCR) amplification of random polymorphic DNA fragments (RAPD), and hypervariable, nuclear-encoded sequences such as minisatellites and microsatellites (Avise, 1994; Ali et al., 2004).

Genetics and Molecular Research 15 (4): gmr.15048829 
In this study, mtDNA sequences and RAPD markers from curimbatá samples collected from four localities in the Paraná River Basin and one locality in the Paraguay River Basin were employed to assess the level of genetic variability within the Paraná-Paraguay River Basin. A major difference between the two river systems is the presence of numerous hydroelectric plants and dams in the Paraná River but not in the Paraguay River. We sequenced $1815 \mathrm{bp}$ from seven PCR-amplified fragments representing five protein-coding mitochondrial genes from 12 individuals and performed RAPD analysis of 56 individuals sampled throughout the region. In the future, this data can be used as a baseline to detect a possible interference in the genetic composition of $P$. lineatus due to restocking and flood control.

\section{MATERIAL AND METHODS}

\section{Mitochondrial DNA analysis}

Adult curimbatá were obtained in 1999 by gill netting from the following localities in the Paraná-Paraguay River Basin (sample sizes given in parentheses are the number of samples collected for the RAPD analysis): Miranda River, a tributary of Paraguay River [MI, N = 4 (10)]; Paraná River, downstream from Itaipú Dam [JI, N = 2 (12)]; Paraná River, downstream from Yaciretá Dam [JY, N = (12)]; Baía River, a tributary of Paraná River [BA, N = 2 (10)], and Corumbá River, a tributary of Paranaíba River [CO, $\mathrm{N}=4$ (12)]. The Paraná River is formed by the junction of Paranaíba and Grande rivers. A general map of the area were samples were collected is shown in Figure 1. Muscle samples from each fish were stored in $95 \% \mathrm{EtOH}$.

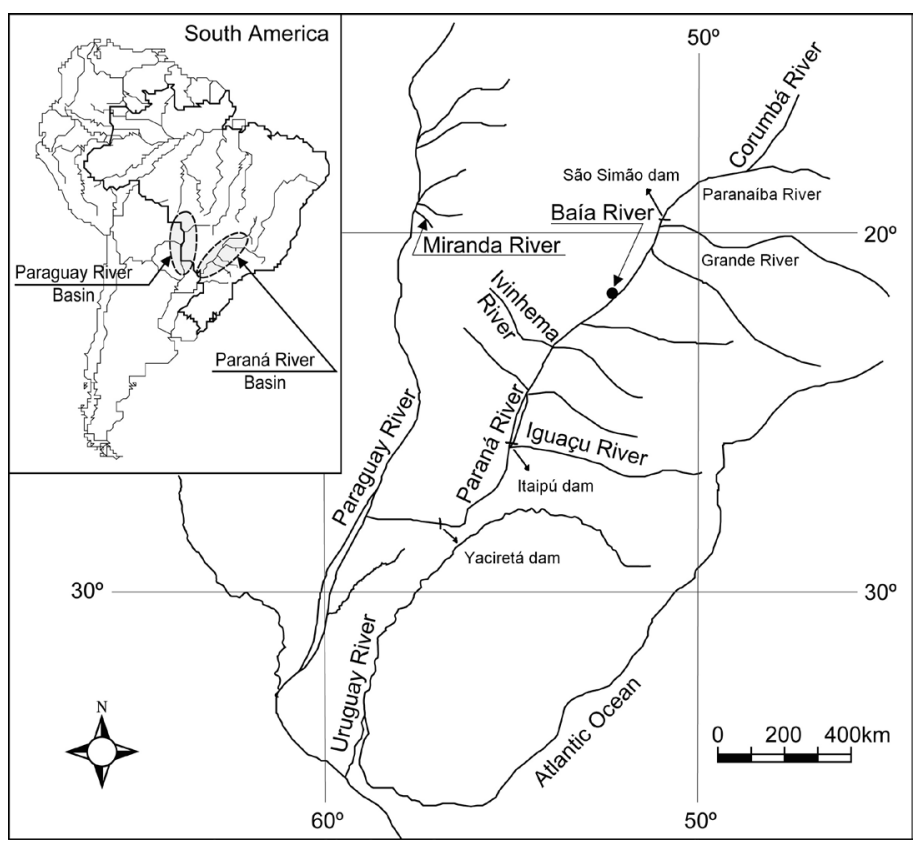

Figure 1. General map of the sampled area. Samples used for both mtDNA and RAPD were collected at the same localities.

Genetics and Molecular Research 15 (4): gmr.15048829 
Samples collected downstream from Yaciretá Dam were not included in the mtDNA analysis because they were not available during the period of research at Texas A\&M University.

Genomic DNA was isolated as described in Gold and Richardson (1991), using approximately $120 \mathrm{mg}$ of EtOH-preserved tissue as starting material. A total of $1815 \mathrm{bp}$ of mtDNA were sequenced (Table 1). PCR amplifications employed primers (5' to $3^{\prime}$ ) as follows: ND2B-L and ND2E-H (Broughton and Gold, 2000) for ND-2; ArgB-L (Bielawski and Gold, 1996) and Nap2 (Arévalo et al., 1994) for ND-4 and ND-4L; COI LB and COI HB (Palumbi, 1994) for COI; and Cyt LA and Cyt HA (Schmidt et al., 1998) for Cyt $b$. Primer sequences are shown in Table 1.

Table 1. Gene name, primer name, primer sequences, and amplified fragment size (bp).

\begin{tabular}{|c|c|c|c|}
\hline Genes & Primers & Primer sequences & Size (bp) \\
\hline \multirow[t]{2}{*}{ ND-2 } & ND2B-L* & 5'-AAGCTTTCGGGCCCATACCC-3' & 277 \\
\hline & ND2E-H* & 5'-TTCTACTTAAAGCTTTGAAGGC-3' & 265 \\
\hline \multirow[t]{2}{*}{ COI } & COI LB & 5'-GCATTCCCACGAATAAATA-3' & \\
\hline & COI HB* & 5'-AGTTATGTGGCTGGCTTGAAA-3' & 293 \\
\hline \multirow[t]{2}{*}{ ND-4L } & ArgB-L* & 5'-CAAGACCCTTGATTTCGGCTCA-3' & 302 \\
\hline & Nap2 & 5'-TGGAGCTTCTACGTGGCTTT-3' & \\
\hline \multirow[t]{2}{*}{ ND-4 } & ArgB-L & 5'-CAAGACCCTTGATTTCGGCTCA-3' & \\
\hline & Nap2* & 5'-TGGAGCTTCTACGTGGCTTT-3' & 288 \\
\hline \multirow[t]{2}{*}{ Cyt $b$} & Cyt LC* & 5'-ATACATGCCAACGGAGCATC-3' & \\
\hline & Cyt HB & 5'-AGTTATGTGGCTGGCTTGAAA-3' & 110 \\
\hline \multirow[t]{2}{*}{ Cyt $b$} & Cyt LA & 5'-GTGACTTGAAAAACCACCGTTG-3' & \\
\hline & Cyt HA* & 5'-CAACGATCTCCGGTTTACAAGAC-3' & 280 \\
\hline Total & & & 1815 \\
\hline
\end{tabular}

*Primers used in sequencing reactions.

PCR thermal profiles generally comprised 25 cycles of denaturation $\left(60 \mathrm{~s}\right.$ at $\left.95^{\circ} \mathrm{C}\right)$, annealing $\left(90 \mathrm{~s}\right.$ at $\left.47^{\circ} \mathrm{C}\right)$, and extension $\left(120 \mathrm{~s}\right.$ at $\left.72^{\circ} \mathrm{C}\right)$. Excess primers, nucleotides, and polymerase were removed from the DNA amplification products, using the Prep-A-Gene ${ }^{\circledR}$ DNA purification system (Bio-Rad laboratories, Inc., Berkeley, CA, USA). DNA amplification products were sequenced by dideoxy cycle sequencing, performed with the Promega FMOL DNA sequencing system, using $\left[{ }^{32} \mathrm{P}\right]$ end-labeled primers. Cycle-sequencing reactions consisted of one cycle of $95^{\circ} \mathrm{C}(120 \mathrm{~s}), 65^{\circ} \mathrm{C}(30 \mathrm{~s})$, and $72^{\circ} \mathrm{C}(30 \mathrm{~s})$, followed by 30 cycles of $95^{\circ} \mathrm{C}(60 \mathrm{~s})$, $65^{\circ} \mathrm{C}(30 \mathrm{~s})$, and $72^{\circ} \mathrm{C}(30 \mathrm{~s})$. Products were electrophoresed on $6 \%$ denaturing polyacrylamide gels, followed by autoradiography. DNA sequences were read manually and confirmed by at least two sequence runs for each individual. Sequences were aligned using GentTool 1.0 (BioTools Inc., Brisbane, QLD, Australia). Sequences were submitted to a BLAST search to confirm amplification of the correct gene and to compare positions of variable sites with the complete genome of Cyprinus carpio (GenBank accession No. X61010.1).

Estimates of pairwise sequence divergence between individuals were computed using the two-parameter model of Kimura (1980). The resulting distance matrix was used to construct a neighbor-joining tree, using MEGA (Kumar et al., 1993). Robustness of the inferred phylogeny was tested by bootstrapping (Felsenstein, 1985). The phylogenetic analysis using parsimony program of Swofford (1991) was used for maximum-parsimony analysis.

\section{RAPD analysis}

The RAPD analyses were performed at Universidade Estadual de Maringá. Genomic

Genetics and Molecular Research 15 (4): gmr.15048829 
DNA extraction was carried out as described by Whitmore et al. (1992), with modifications described by Sekine et al. (2002). The amount and quality of the DNA was estimated by $1 \%$ agarose gel electrophoresis in 0.5X TBE buffer (Sambrook et al., 1989) and comparison with known amounts of $\lambda$ DNA. Genomic DNA of two individuals from each of the five locations (MI, JI, JY, BA, and CO) was used as templates for RAPD marker amplification, using the following primer kits: OPA, OPX, and OPW (Operon Technologies, Inc., Alameda, CA, USA). Primer pairs exhibiting the highest quality banding patterns, repeatability, and variability among individuals were selected for subsequent amplification.

Arbitrarily primed amplifications were performed in a Peltier thermal cycler (PTC$100 \mathrm{HB}-60$, MJ Research Inc.). Amplification reactions were performed with $10 \mathrm{ng}$ DNA, 0.46 $\mu \mathrm{M}$ each primer, $1 \mathrm{U}$ Taq polymerase (Gibco BRL), $200 \mu \mathrm{M}$ each dNTP, $2 \mathrm{mM} \mathrm{MgCl}{ }_{2}$, and $1 \mathrm{X}$ Taq buffer, totaling $13 \mu \mathrm{L}$. The thermal program for amplification was 4 min at $92^{\circ} \mathrm{C}$, followed by 40 cycles of $60 \mathrm{~s}$ at $92^{\circ} \mathrm{C}, 90 \mathrm{~s}$ at $40^{\circ} \mathrm{C}$, and $120 \mathrm{~s}$ at $72^{\circ} \mathrm{C}$, and a final cycle of $5 \mathrm{~min}$ at $72^{\circ} \mathrm{C}$ (Almeida et al., 2001). PCR products were electrophoresed on $1.4 \%$ agarose gels run in TBE buffer (0.09 M Tris-Borato, $1 \mathrm{mM}$ EDTA), stained with ethidium bromide $(0.02 \%)$, and visualized by UV light illumination.

Polymorphism was scored on a presence or absence basis. The Fisher exact test was performed using the tools for population genetic analysis program (Miller, 1997), to verify the existence of significant differences in band frequencies of pairwise comparisons and of the total population.

\section{RESULTS}

\section{mtDNA analysis}

Twelve individuals representing four geographic regions were sequenced for 1815 bp mtDNA. Sequences obtained included 542 bp ND-2, 293 bp COI, 288 bp ND-4, 302 bp ND-4L (including 12 bp tRNA arg), and 390 bp Cyt $b$ (Table 1). Nucleotide sequences were deposited in GenBank under the accession Nos: AY115366.1-AY 11537.1 and AY115354AY115365.1 (ND-2); AY115307.1-AY115318.1 (ND-4); AY115378.1-AY115389.1 (ND-4L); AY115319.1-AY115330.1 (COI); AY 115343.1-AY115353.1 and AY115335.1-AY115342.1 $($ Cyt $b)$. Thirty variable positions $(1.65 \%)$ were identified, all of which were transitions. No insertions, deletions, or amino acid substitution were detected. A total of $11 \mathrm{mtDNA}$ genotypes (haplotypes) were observed among the 12 individuals; two individuals (one individual from the Paraná River (JI-1) and one from the Corumbá River (CO-4) were identical (Table 2). The percent nucleotide sequence divergence (Kimura, 1980) was $0.47 \pm 0.06$ (means \pm SD) and ranged from 0.00 to 0.95 (Table 3 ).

The largest divergence $(0.95 \%)$ was between haplotype CO-2 from the Corumbá River (tributary of Paranaíba River in Paraná River system) and haplotype MI-2 from the Miranda River (Paraguay River system). As the Corumbá River represents the northernmost sample locality in the Paraná River system, and the Miranda River is located in the northern section of the Paraguay River system, this might suggest genetic divergence between these two extreme sample localities. Apart from haplotypes JI-1 and CO-4, which possessed identical mtDNA haplotypes, the second most similar haplotypes (with a sequence difference of $0.06 \%$ ) were CO-2 and MI-3. Furthermore, among the most genetically similar haplotypes (sequence difference of $0.17 \%$ ) were CO-1 and MI-1, and CO-1 and MI-3.

Genetics and Molecular Research 15 (4): gmr.15048829 
E. Revaldaves et al.

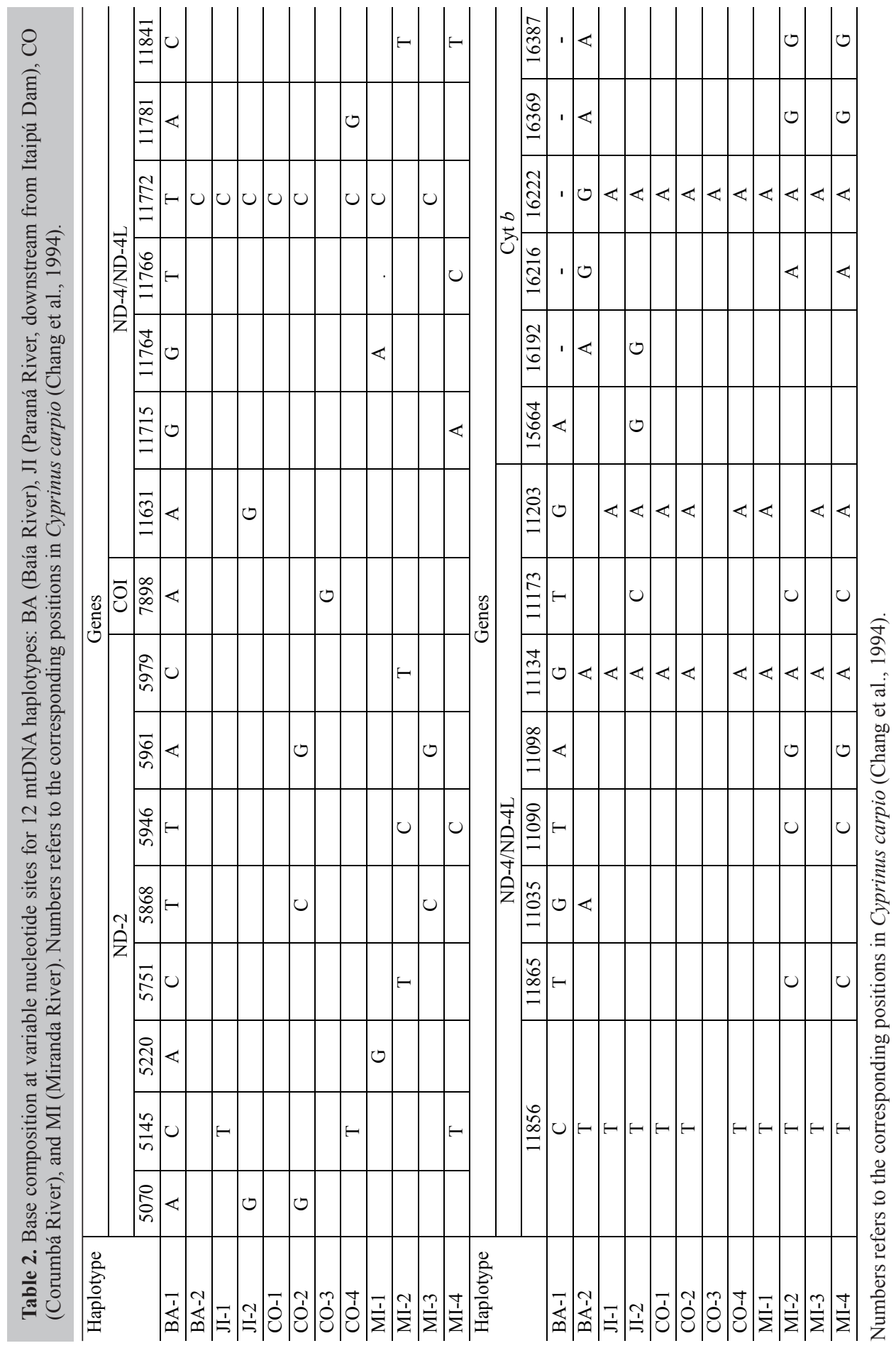

Genetics and Molecular Research 15 (4): gmr.15048829 
Table 3. Sequence divergence (\%) between mtDNA haplotypes from Baía River (BA), Paraná River, downstream from Itaipú Dam (JI), Corumbá River (CO), and Miranda River (MI).

\begin{tabular}{|c|c|c|c|c|c|c|c|c|c|c|c|}
\hline & BA-2 & JI-1 & JI-2 & $\mathrm{C} 0-1$ & $\mathrm{CO}-2$ & $\mathrm{CO}-3$ & CO-4 & MI-1 & MI-2 & MI-3 & MI-4 \\
\hline BA-1 & 0.39 & 0.52 & 0.59 & 0.46 & 0.59 & 0.07 & 0.52 & 0.52 & 0.86 & 0.52 & 0.92 \\
\hline BA-2 & & 0.28 & 0.39 & 0.22 & 0.33 & 0.33 & 0.28 & 0.28 & 0.83 & 0.28 & 0.89 \\
\hline JI-1 & & & 0.33 & 0.17 & 0.28 & 0.39 & 0.00 & 0.22 & 0.78 & 0.22 & 0.72 \\
\hline JI-2 & & & & 0.28 & 0.28 & 0.50 & 0.33 & 0.33 & 0.89 & 0.33 & 0.83 \\
\hline CO-1 & & & & & 0.22 & 0.33 & 0.17 & 0.17 & 0.83 & 0.17 & 0.78 \\
\hline $\mathrm{CO}-2$ & & & & & & 0.44 & 0.28 & 0.28 & 0.95 & 0.06 & 0.89 \\
\hline CO-3 & & & & & & & 0.39 & 0.39 & 0.83 & 0.39 & 0.89 \\
\hline $\mathrm{CO}-4$ & & & & & & & & 0.22 & 0.78 & 0.22 & 0.72 \\
\hline MI-1 & & & & & & & & & 0.89 & 0.22 & 0.83 \\
\hline MI-2 & & & & & & & & & & 0.89 & 0.28 \\
\hline MI-3 & & & & & & & & & & & 0.83 \\
\hline
\end{tabular}

The maximum-parsimony analysis produced a total of seven trees, each with a branch length of 23 and a CI of 0.826 . The $50 \%$ majority rule consensus tree (not shown) resulted in a largely unresolved polychotomy. The neighbor-joining tree obtained using estimates of sequence divergence is shown in Figure 2. Clades identified in the neighbor-joining tree were those that were supported by at least $75 \%$ in the bootstrap analysis (MI-2 and MI-4; CO-3 and BA-1; CO-2 and MI-3; JI-1 and CO-4).

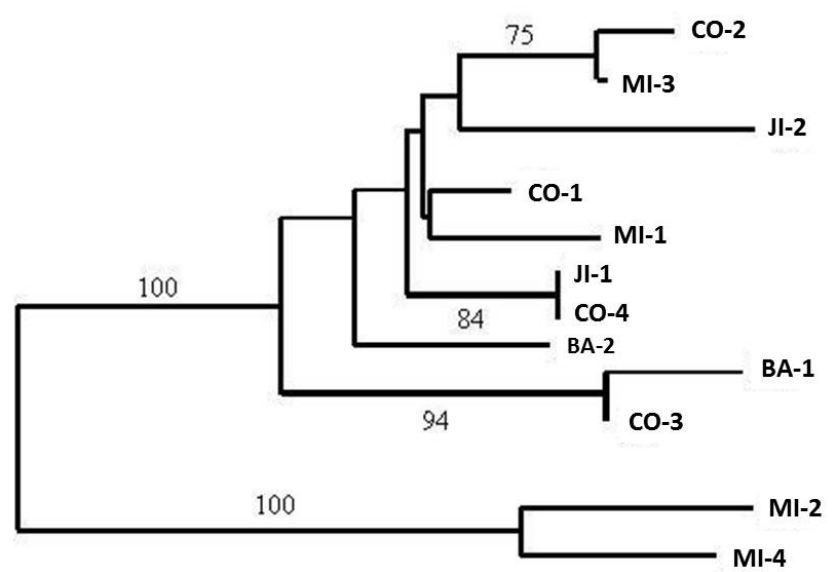

Figure 2. Neighbor-joining topology generated using combined ND-4, ND-4L, ND-2, and Cyt $b$ nucleotide sequence data (1815 bp total). Bootstrap percentages $\geq 75 \%$ are reported on branches.

\section{RAPD analysis}

The seven random primers produced 86 scorable bands. The number of bands varied from four to 19 and the approximate band sizes varied from 250 to $2200 \mathrm{bp}$ (Table 4). Fisher's exact tests of homogeneity of band frequencies over all samples and between pairs of samples were non-significant (data not shown). 
Table 4. Random primers used in the comparison of curimbatá (Prochilodus lineatus) samples from the Paraná River: number $(\mathrm{N})$ of amplified scorable bands and their size (bp).

\begin{tabular}{l|l|c|c}
\hline Primer & Nucleotide sequence (5'-3') & N & Size (bp) \\
\hline OPW9 & GTGACCGAGT & 4 & $710-1750$ \\
\hline OPA16 & AGCCAGCGAA & 10 & $710-1220$ \\
\hline OPA18 & AGGTGACCGT & 15 & $300-1400$ \\
\hline OPA19 & CAAACGTCGG & 10 & $610-1950$ \\
\hline OPX10 & TCGCATCCCT & 18 & $300-2100$ \\
\hline OPX15 & GAGGCCAGGA & 10 & $250-2100$ \\
\hline OPX20 & CCCAGCTAGA & 18 & $290-2200$ \\
\hline
\end{tabular}

\section{DISCUSSION}

Considerable variation in mtDNA was observed among the curimbatá samples. Eleven haplotypes were identified among the 12 individuals representing four discrete sampling locations in the Paraná-Paraguay River Basin. Sivasundar et al. (2001) also found comparatively high levels of sequence diversity in the mtDNA D-loop, ATPase 6, and ATPase 8 genes among curimbatá from the Paraná River Basin. Likewise, Revaldaves et al. (1997) observed high levels of allozyme polymorphism in three curimbatá samples from the upper Paraná River. In both these studies, no significant genetic divergence was observed among geographic samples (Revaldaves et al., 1997; Sivasundar et al., 2001). Low levels of mtDNA variability have also been observed in other species of genus Prochilodus. Turner et al. (2004), for example, found very low levels of ND-4 and COI sequence diversity in Prochilodus rubrotaeniatus and Prochilodus mariae throughout South America; out of six sampled localities of $P$. mariae, five had the same mtDNA haplotype and only a single mtDNA haplotype was observed in $P$. rubrotaeniatus.

Estimates of mtDNA sequence divergence observed among the curimbatá assayed (independent of geographic locality) were $\leq 1 \%$, with a mean divergence of $0.47 \%$. These values are smaller than those reported for other groups of fishes, in which the reported conspecific mtDNA sequence divergence values typically range from $\sim 3.8$ to $6 \%$ (McCune and Lovejoy, 1998; Dergam et al., 1998). The neighbor-joining tree obtained using mtDNA sequence divergence estimates revealed no stable patterns of geographic partitioning. Garcez et al. (2011) used PCR-RFLP among 141 specimens of $P$. lineatus from eight collection sites in the Grande River Basin (Paraná River Basin) and found only a single population. Our own RAPD band analysis also revealed high genetic similarity among curimbatá sampled in the Paraná-Paraguay River Basin, with no significant differences in band frequencies observed neither among samples nor in the pairwise sample locality comparisons.

Thus, both the mtDNA and RAPD data indicate substantial gene flow among curimbatá within the Paraná and Paraguay river systems prior to the construction of dams and that up to the time of sample collection, the construction of dams had neither restricted movement nor altered the genetic compositions of the species. Results obtained in this study thus corroborate the findings of Sivasundar et al. (2001), Revaldaves et al. (1997), and Garcez et al. (2011), suggesting that the curimbatá from the upper and middle stretches of the Paraná River Basin represent a single population and that the Canal da Piracema, constructed in 2002 to connect the middle and upper stretch of Paraná River, does not represent a menace to the curimbatá gene pool. Based on these findings, future stocking programs of the curimbatá, if implemented, must consider the possibility of genetic divergence in the lower portion of the Paraná River. Ramella et al. (2006) suggested the existence of different populations of curimbatá in the

Genetics and Molecular Research 15 (4): gmr.15048829 
Uruguay River Basin. In their study, 29 polymorphic RAPD fragments obtained from 11 individuals from two localities ( $\mathrm{N}=4$ and $\mathrm{N}=7$, respectively) in the Uruguay River Basin revealed high genetic variability among individuals collected in the same location.

Although the RAPD technique can provide quick and relatively inexpensive analysis of the genetic variability, it presents some disadvantages (e.g., dominance, reproducibility, homology inferences, and artifact fragments), compared to co-dominant markers. The PCR primers for nuclear-encoded microsatellites for Prochilodus described by Barbosa et al. (2008), Carvalho-Costa et al. (2006), and Yazbeck and Kalapothakis (2007) would prove useful for further genetic monitoring of curimbatá once codominant inheritance of the microsatellite alleles is substantiated. Complex hypervariable repeats can also be tested in future analyses since Barroca et al. (2012) verified a significant population differentiation at the 2V35 molecular marker in Prochilodus costatus from Pará River (Minas Gerais).

\section{Conflicts of interest}

The authors declare no conflict of interest.

\section{ACKNOWLEDGMENTS}

We thank L. Richardson for her guidance during laboratory activities at Texas A\&M University, C.P. Burridge for the help with PAUP, and T. Clark and P. Loret for sequence submission assistance. We also thank P.J.L.L. Pereira for drawing the map; A.J. Prioli and S.M.P. Prioli for supplying the laboratory infrastructure for completion of RAPD analysis at Universidade Estadual de Maringá; A.S. Fennocchio, C. Navarrete, Nupélia, Promissão, and Iaipu Hydropower staff helped with fish sample collection. CAPES and CNPq provided grants for this doctorate research. Research at Texas A\&M University was supported in part by Texas AgriLife Research under project H-6703.

\section{REFERENCES}

Agostinho AA, Miranda LE, Bini LM, Gomes LC, et al. (1999). Patterns of colonization in Neotropical reservoirs and prognoses on aging. In: Theoretical reservoir ecology and its applications (Tundisi JG and Straškraba M, eds.). International Institute of Ecology, Brazilian Academy of Sciences and Backhuys Publishers, São Carlos, 227-265.

Agostinho AA, Thomaz SM and Gomes LC (2005). Conservation of the biodiversity of Brazil's inland waters. Conserv. Biol. 19: 646-652. http://dx.doi.org/10.1111/j.1523-1739.2005.00701.x

Agostinho AA, Gomes LC and Pelicice FM (2007). Ecologia e manejo de recursos pesqueiros em reservatórios do Brasil. EDUEM, Maringá.

Agostinho AA, Pelicice FM and Gomes LC (2008). Dams and the fish fauna of the Neotropical region: impacts and management related to diversity and fisheries. Braz. J. Biol. 68 (Suppl): 1119-1132. http://dx.doi.org/10.1590/S1519$\underline{69842008000500019}$

Agostinho AA, Bonecker CC and Gomes LC (2009). Effects of water quantity on connectivity: the case of the upper Paraná River floodplain. Ecohydrol. Hydrobiol. 9: 99-113. http://dx.doi.org/10.2478/v10104-009-0040-x

Ali BA, Huang TH, Qin DN and Wang XN (2004). A review of random amplified polymorphic DNA (RAPD) markers in fish research. Rev. Fish Biol. Fish. 14: 443-453. http://dx.doi.org/10.1007/s11160-005-0815-0

Allendorf FW, Ryman N and Utter FM (1987). Genetic and fisheries management: past, present and future. In: Population genetics and fishery management (Ryman N and Utter FM, eds.). University of Washington Press, Seattle, 1-19.

Almeida FS, Fungaro MHP and Sodré LMK (2001). RAPD and isozyme analysis of genetic variability in three allied species of catfish (Siluriformes: Pimelodidae) from the Tibagi River, Brazil. J. Zool. 253: 113-120. http://dx.doi. org/10.1017/S0952836901000103

Genetics and Molecular Research 15 (4): gmr.15048829 
Arévalo E, Davis SK and Sites Jr JW (1994). Mitochondrial DNA sequence divergence and phylogenetic relationships among eight chromosome races of the Sceloporus grammicus complex (Phrynosomatidae) in Central Mexico. Syst. Biol. 43: 387-418. http://dx.doi.org/10.1093/sysbio/43.3.387

Avise JC (1994). Molecular markers, natural history and evolution. Chapman and Hall, New York.

Barbosa ACDR, Galzerani F, Corrêa TC, Galetti Jr PM et al. (2008). Description of novel microsatellite loci in the Neotropical fish Prochilodus argenteus and cross-amplification in P. costatus and P. lineatus. Genet. Mol. Biol. 31: 357-360. http://dx.doi.org/10.1590/S1415-47572008000200032

Barroca TM, Santos GB, Duarte NV and Kalapothakis E (2012). Evaluation of genetic diversity and population structure in a commercially important freshwater fish Prochilodus costatus (Characiformes, Prochilodontidae) using complex hypervariable repeats. Genet. Mol. Res. 11: 4456-4467. http://dx.doi.org/10.4238/2012.September.27.4

Bielawski JP and Gold JR (1996). Unequal synonymous substitution rates within and between two protein-coding mitochondrial genes. Mol. Biol. Evol. 13: 889-892. http://dx.doi.org/10.1093/oxfordjournals.molbev.a025649

Broughton RE and Gold JR (2000). Phylogenetic relationships in the North American cyprinid genus Cyprinella (Actinopterygii: Cyprinidae) based on sequences of the mitochondrial ND2 and ND4L genes. Copeia 1: 1-10. http:// dx.doi.org/10.1643/0045-8511(2000)2000[0001:PRITNA]2.0.CO;2

Carvalho-Costa LF, Hatanaka T and Galetti Jr PM (2006). Isolation and characterization of polymorphic microsatellite markers in the migratory freshwater fish Prochilodus costatus. Mol. Ecol. Notes 6: 818-819. http://dx.doi.org/10.1111/ j.1471-8286.2006.01356.x

Chang Y, Huang F and Lo T (1994). The complete nucleotide sequence and gene organization of carp (Cyprinos carpio) mitochondrial genome. J. Mol. Evol. 38: 138.

Companhia Energética de São Paulo CESP (1996). Aspectos limnológicos, ictiológicos e pesqueiros de reservatórios da CESP no período de 1986 a 1994. CESP-Série Pesquisa e Desenvolvimento, São Paulo, 136.

Dergam JA, Suzuki HI, Shibatta OA, Duboc LF, et al. (1998). Molecular biogeography of the Neotropical fish Hoplias malabaricus (Erythrinidae: Characiformes) in the Iguaçu, Tibagi, and Paraná rivers. Genet. Mol. Biol. 21: 493-496. http://dx.doi.org/10.1590/S1415-47571998000400015

Felsenstein J (1985). Confidence limits on phylogenies: an approach using the bootstrap. Evolution 39: 783-791. http:// dx.doi.org/10.2307/2408678

Ferguson M (1994). The role of molecular genetic markers in the management of cultured fishes. Rev. Fish Biol. Fish. 4: 351-373. http://dx.doi.org/10.1007/BF00042909

Garcez R, Galcagnotto A and De Almeida-Toledo LF (2011). Population structure of migratory fish Prochilodus lineatus (Characiformes) from Rio Grande basin (Brazil), an area fragmented by dams. Aquat. Conserv. 21: 268-275. http:// dx.doi.org/10.1002/aqc. 1176

Gold JR and Richardson LR (1991). Genetic studies in marine fishes. IV. An analysis of population structure in the red drum (Sciaenops ocellatus) using mitochondrial DNA. Fish. Res. 12: 213-241. http://dx.doi.org/10.1016/0165$\underline{7836(91) 90096-X}$

Gomes LC and Agostinho AA (1997). Influence of the flooding regime on the nutritional state and juvenile recruitment of the curimba, Prochilodus scrofa, Steindachner, in the upper Paraná River, Brazil. Fish. Manag. Ecol. 4: 263-274. http://dx.doi.org/10.1046/j.1365-2400.1997.00119.x

Gubiani EA, Gomes LC, Agostinho AA and Okada EK (2007). Persistence of fish populations in the upper Paraná River, effects of water regulation by dams. Ecol. Freshwat. Fish 16: 191-197.

Kimura M (1980). A simple method for estimating evolutionary rates of base substitutions through comparative studies of nucleotide sequences. J. Mol. Evol. 16: 111-120. http://dx.doi.org/10.1007/BF01731581

Kumar SK, Tamura K and Nei M (1993). MEGA: molecular evolutionary genetics analysis, version 1.02. Pennsylvania State University, University Park.

McCune AR and Lovejoy NR (1998). The relative rate of sympatric and allopatric speciation in fishes: tests using DNA sequence divergence between sister species and among clades. In: Endless forms: species and speciation (Howard D and Berloccher SH, eds.). Oxford University Press, Oxford, 172-185.

Miller MP (1997). Tools for population genetics analyses (TFPGA) version 1.03. Available at [www.marksgeneticsoftware. net/tfpga.htm]. Accessed July 4, 2016.

Palumbi SR (1994). Genetic divergence, reproductive isolation, and marine speciation. Annu. Rev. Ecol. Syst. 25: 547-572. http://dx.doi.org/10.1146/annurev.es.25.110194.002555

Ramella MS, Kroth MA, Meurer S, Nuñer APO, et al. (2006). Genetic variability in four fish species (Pimelodus maculatus, Prochilodus lineatus, Salminus brasiliensis and Steindachneridion scripta) from Uruguay River basin. Braz. Arch. Biol. Technol. 49: 589-598. http://dx.doi.org/10.1590/S1516-89132006000500008

Resende EK, Catella AC, Nascimento F, Palmeira SS, et al. (1996). Biologia do curimbatá (Prochilodus lineatus), pintado (Pseudoplatystoma corruscans) e cachara (Pseudoplatystoma fasciatum) na bacia hidrográfica do rio Miranda, Pantanal de Mato Grosso do Sul, Brasil. EMBRAPA-CPAP, Corumbá.

Genetics and Molecular Research 15 (4): gmr.15048829 
Revaldaves E, Renesto E and Machado MFPS (1997). Genetic variability of Prochilodus lineatus (Characiformes, Prochilodontidae) in the upper Paraná River. Bras. J. Genet. 20: 381-388.

Rossi L, Cordiviola de Yuan E and Parma MJ (2007). Fishes. In: The Middle Paraná River: limnology of a subtropical wetland (Iriondo M, Paggi JJ and Parma MJ, eds.). Springer-Verlag, Berlin, 305-325.

Sambrook J, Fritsch EF and Maniatis T (1989). Molecular cloning: a laboratory manual. 2nd ed. Cold Spring Harbour Laboratory Press, New York.

Schmidt TR, Bielawski JP and Gold JR (1998). Molecular phylogenetics and evolution of the cytochrome b gene in the cyprinid genus Lythrurus (Actinopterygii: Cypriniformes). Copeia 1998: 14-22. http://dx.doi.org/10.2307/1447697

Sekine ES, Prioli AJ, Prioli SMAP and Júlio Jr HF (2002). Genetic differentiation among populations of Pseudoplatystoma corruscans (Agassiz, 1829) (Osteichthyes, Pimelodidae) isolated by the Guaíra Falls in the Paraná River. Acta Scientiarum 24: 507-512.

Sivasundar A, Bermingham E and Ortí G (2001). Population structure and biogeography of migratory freshwater fishes (Prochilodus: Characiformes) in major South American rivers. Mol. Ecol. 10: 407-417. http://dx.doi.org/10.1046/ j.1365-294x.2001.01194.x

Swofford DL (1991). PAUP: phylogenetic analysis using parsimony. Illinois Natural History Survey, Champaign.

Turner TF, McPhee MV, Campbell P and Winemiller KO (2004). Phylogeography and intraspecific genetic variation of prochilodontid fishes endemic to rivers of northern South America. J. Fish Biol. 64: 186-201. http://dx.doi. org/10.1111/j.1095-8649.2004.00299.x

Whitmore DH, Thai TH and Craft CM (1992). Gene amplification permits minimally invasive analysis of fish mitochondrial DNA. Trans. Am. Fish. Soc. 121: 170-177. http://dx.doi.org/10.1577/1548-8659(1992)121<0170:GAPMIA>2.3.CO;2

Yazbeck GM and Kalapothakis E (2007). Isolation and characterization of microsatellite DNA in the piracema fish Prochilodus lineatus (Characiformes). Genet. Mol. Res. 6: 1026-1034.

Genetics and Molecular Research 15 (4): gmr.15048829 